\title{
O ANJO DA HISTÓRIA E A MEMÓRIA DAS VIITIMAS: O CASO DA DITADURA MILITAR NO BRASIL ${ }^{1}$
}

José Carlos Moreira da Silva Filho*

RESUMO - O artigo se apóia na filosofia da história da Walter Benjamin para denunciar a barbárie que se aloja na base da sociedade ocidental e promove a exclusão e o esquecimento das vítimas. Indica o papel político da memória na construção da democracia e no resgate da dignidade humana, reconhecida a partir da alteridade evidenciada no sofrimento, seguindo mais de perto a experiência das ditaduras latinoamericanas, em especial, a da ditadura militar brasileira.

PALAVRAS-CHAVE - Justiça das vítimas. Memória política. História e narração. Dignidade da pessoa humana. Ditadura Militar. Walter Benjamin.
ABSTRACT - This article uses Walter Benjamin's philosophy of history in order to expose the barbarism that is located in the western society foundations, which promotes exclusion and victim's forgetfulness. The paper indicates the political role of memory in building democracy and rescuing the human dignity, which is recognized from suffering's alterity. The article will focus the experience of Latin American dictatorships and, more particularly, the military dictatorship in Brazil.

KEY WORDS - Victim's justice. Political Memory. History and narration. Human person dignity. Military dictatorship. Walter Benjamin.

* Doutor em Direito das Relações Sociais pela Universidade Federal do Paraná - UFPR, Professor do Programa de Pós-graduação em Direito e da Graduação em Direito da UNISINOS, Conselheiro da Comissão de Anistia do Ministério da Justiça.

1 Este artigo é a versão escrita da palestra proferida no III Simpósio da Cátedra UnescoUnisinos Direitos Humanos e violência, governo e governança, no Painel "Justiça e memória. O esquecimento das vítimas, uma segunda injustiça", ocorrido no dia 19 de maio de 2008 no Auditório Central da UNISINOS-RS. A mesa foi compartilhada com o filósofo Ricardo Timm de Souza. Este artigo é também resultado parcial do projeto de pesquisa "Pessoa Humana e Sujeito de Direito nas Relações Jurídico-Privadas: identidade e alteridade", coordenado pelo Prof. Dr. José Carlos Moreira da Silva Filho e financiado pela UNISINOS.

\begin{tabular}{|l|l|l|l|l|l|} 
VERITAS & Porto Alegre & v. 53 & n. 2 & abr./jun. 2008 & p. 150-178
\end{tabular}


Todos foram saindo, de mansinho tão calados, que eu nem sei se fiquei mesmo só.

Não trouxe mensagem e não me deram senha...

Disseram-me que não iria perder nada, Porque não há mais céu. $E$ agora, que tenho medo, e estou cansado, mandam-me embora...

Mas não quero ir para mais longe, desterrado, porque a minha pátria é a memória. Não, não quero ser desterrado, Que a minha pátria é a memória...

(JoÃo GUIMARÃES ROSA - Magma)

\section{Sofrimento e barbárie}

A política do século XX assume uma nova feição: é uma política de luto na qual a principal arma é a memória. A sociedade de hoje deixou atrás de si um rastro de destruição, morte e sofrimento. Ao longo do século XX, com as duas grandes guerras, e em especial com os campos de concentração nazistas, a humanidade testemunhou o ápice da degradação humana, a desumanidade em níveis até então inimagináveis. Pela primeira vez um Estado decide, com o aparato técnico fornecido pela sociedade industrial, eliminar todo um grupo humano².

Nessa metódica, técnica e burocrática tarefa de eliminação, o que delimita o grupo a ser exterminado não são motivos utilitaristas, interesses econômicos ou políticos localizados, nem mesmo paixões violentas que desencadeiam o ódio e o instinto assassino, mas simplesmente uma determinada característica que é inerente às pessoas que compõem este grupo.

2 É o que enfatiza Reyes Mate ao explicar a singularidade de Auschwitz, acrescentando, ainda, que tal ineditismo também está presente no grau de maldade exercido, o que se torna visível na absoluta frieza com que, em escala industrial, se procurava não só a eliminação jurídica, moral e física da pessoa, mas também dos seus rastros. É "a negação do crime dentro do crime mesmo (...) Organizar o crime de modo que não haja nem testemunhos para certificar sua existência, nem restos materiais que pudessem servir para reconstruí-lo" (MATE, Reyes. Memórias de Auschwitz - atualidade e política. Tradução de Antonio Sidekum. São Leopoldo: Nova Harmonia, 2005. p. 174). Os corpos eram queimados, os ossos eram triturados e o pó era jogado ao vento. Famílias inteiras simplesmente desapareceram da face da terra. 
No caso do nazismo, o simples fato de alguém ter nascido judeu era o suficiente para que contra si fosse iniciado o processo de desumanização e de extermínio.

No campo, não ocorria apenas a eliminação física dos internos, antes que isto ocorresse eles eram privados de sua identidade jurídica, perdendo a sua nacionalidade e ficando totalmente fora-da-lei e desprotegido ${ }^{3}$. A existência ou não de culpa era totalmente irrelevante, visto que eram inimigos objetivos, para os quais de nada valiam os direitos humanos. Após a morte jurídica vinha a morte moral. A própria escolha moral era eliminada. Nem mesmo a morte podia ser uma opção, pois o suicídio poderia representar o assassinato de todos os amigos e familiares. A pessoa perdia sua voz, de nada adiantava protestar. O horror dos campos de concentração é difícil de ser imaginado, pois ele está além da vida e da morte. Ambas não pertencem mais à pessoa, sua existência e sua memória são simplesmente apagadas da face da Terra ${ }^{4}$. Tudo era organizado para não deixar rastros nem testemunhas.

O que está em jogo a partir de Auschwitz não é ser bom ou ser mal, mas ser humano. A parafernália técnica da morte a serviço do genocídio atenta contra a própria humanidade, pois cria uma justificativa (que é simplesmente a do seu próprio acionamento) para eliminar parcelas inteiras da humanidade. Esta vai sendo pulverizada em sua diversidade e espontaneidade. Daí que quando se fala em ética tem-se, agora, um novo ponto de partida. Theodor Adorno assim o delimitou:

Hitler ha impuesto a los hombres en estado de no-libertad un nuevo imperativo categórico: orientar su pensamiento y su acción de tal modo que Auschwitz no se repita, que no ocurra nada parecido 5 .

O sofrimento é, portanto, o ponto de partida de uma ética negativa. O refugo passa a ser uma nova referência do humano, tomando o lugar da dignidade humana e suas abstrações. Não se trata de buscar um princípio racional que sirva de base para a elaboração de catálogos de conduta. No campo da ética, há algo que se antecipa a qualquer formulação racional com pretensões fundadoras. Este algo foi dito de modo decisivo por Adorno: "La necesidad de prestar voz al sufrimiento es condición de toda verdad"6.

3 ARENDT, Hannah. Origens do totalitarismo - anti-semitismo, imperialismo e totalitarismo. Tradução de Roberto Raposo. São Paulo: Companhia das Letras, 1989. p. 498.

4 Ibidem, p. 501-503.

5 ADORNO, Theodor W. Dialectica negativa. Tradução de Alfredo Brotons Muñoz. Madrid: Akal, 2005. p. 334.

6 Ibidem, p. 28. No mesmo sentido, afirma também Adorno na sua Mínima moralia quando critica as atitudes de condescendência diante do sofrimento: "Toda a participação, toda a humanidade do trato e da partilha são simples máscara da tácita aceitação do inumano. Há que tornarse consonante com o sofrimento dos homens: o mais pequeno passo para o seu contentamento é ainda um passo para o endurecimento do sofrimento" (ADORNO, Theodor W. Mínima moralia. Tradução de Artur Morão. Lisboa: Edições 70, 2001. p. 19). 
A dignidade humana advém de um saber medir-se com a morte que ficou para trás, não apenas com a que está à frente, esperando por cada um

A era da técnica trouxe consigo um mal radical. Ele está muito além daquela maldade atribuída aos instintos mais baixos que individualmente alguém pode ostentar. $\mathrm{O}$ mal radical está presente em todo um sistema social que permite o acionamento dos processos industriais e burocráticos de desumanização e extermínio sem que os carrascos e todos os envolvidos se sintam minimamente responsáveis pelo que fazem. O carrasco não se sente culpado, mas incompreendido, pois imagina estar cumprindo o seu dever ${ }^{8}$. Todos os demais, os espectadores, são cúmplices em sua indiferença, pois o crime não teria ocorrido sem a sua muda aceitação ${ }^{9}$. Ninguém pode

7 Martin Heidegger pensou a morte como um limite existencial do humano. Ao se conduzir a vida com a consciência de que se é para-a-morte, as escolhas e decisões assumem uma condição autêntica, visto que embebidas na temporalidade e conscientes da fragilidade de todo 0 projeto humano, acuado entre o seu lançamento, sem que sua consciência tenha escolhido o início ou os fundamentos de si mesma, já que a existência precede a consciência, e o imprevisível acontecimento da sua morte, daquela possibilidade que elimina todas as outras. Exatamente por isto, explica Reyes Mate, é que a condição do interno no campo de concentração é desumana, pois a morte não é mais uma possibilidade cuja data é incerta, ela é uma facticidade. "Ora, no campo não se dá essa possibilidade da autenticidade porque não existe nenhuma distância entre a vida e seu final. A morte não é uma possibilidade, mas uma facticidade" (MATE, op. cit., p. 211). Em seu romance intitulado 0 idiota, Dostoievski projeta sua própria experiência de condenado à morte por "conspiração política", sentença comutada no último instante, e dá voz a Míchkin, personagem central, cuja principal característica é o respeito incondicional pela vida, tida como valor supremo. Míchkin afirma que a morte por sentença é uma "profanação da alma". Diz ele: "E todavia a dor principal, a mais forte, pode não estar nos ferimentos e sim, veja, em você saber, com certeza, que dentro de uma hora, depois dentro de dez minutos, depois dentro de meio minuto, depois agora, neste instante - a alma irá voar do corpo, que você não vai mais ser uma pessoa, e que isso já é certeza; e o principal é essa certeza" (DOSTOIÉVSKI, Fiódor. O idiota. Tradução de Paulo Bezerra. São Paulo: Editora 34, 2002). De todo modo, pelo viés da ética negativa e pela política messiânica de Walter Benjamin (a ser referida mais adiante), a condição do humano, para ser resgatada em sua humanidade, deve medir-se com a barbárie, o sofrimento e a morte que estão nos porões da civilização. Por mais impossível que seja descrevê-los, a sua rememoração é o critério ético e ontológico fundamental.

8 É o que se torna possível constatar no discurso de muitos militares e torturadores que se envolveram diretamente nas ações repressivas durante as ditaduras latino-americanas. Muito líderes da repressão no Cone-Sul foram considerados verdadeiros patriotas, pois para eliminar o inimigo objetivo da pátria (no caso o comunista) tudo era permitido, inclusive a própria desumanidade.

9 Referindo-se aos apátridas e refugiados judeus Hannah Arendt pondera que a situação angustiante na qual estavam envolvidos "não resulta do fato de não serem iguais perante a lei, mas sim de não existirem mais leis para eles; não de serem oprimidos, mas de não haver ninguém mais que se interesse por eles, nem que seja para oprimi-los. Só no último estágio de um longo processo o seu direito à vida é ameaçado; só se permanecerem absolutamente 'supérfluos', se não se puder encontrar ninguém para 'reclamá-los', as suas vidas podem correr perigo. Os próprios nazistas começaram a sua exterminação dos judeus privando-os, primeiro de toda condição legal (isto é, da condição de cidadãos de segunda classe) e separando-os do mundo para ajuntá-los em guetos e campos de concentração; e, antes de acionarem as câmaras de gás, haviam apalpado cuidadosamente o terreno e verificado, para sua satisfação, que nenhum país reclamava aquela gente" (ARENDT, op. cit., p. 329). 
se declarar neutro diante do ocorrido. Para Reyes Mate, este é o sentido da expressão de Agamben de que "tudo é campo".

Esse mal radical, porém, contrariamente ao que a advertência de Adorno (lembrar para que não aconteça de novo) poderia conduzir, aconteceu novamente, e continua acontencendo: Guantânamo, Camboja, Ruanda, Kosovo, Nahr Al Bared, as ditaduras do Cone-Sul da América Latina. E o que é pior, o padrão de redução do humano para a "vida nua"10 se espalha para fora dos campos de concentração propriamente ditos. Quando Agamben, portanto, afirma que "tudo é campo" ele sinaliza para a adoção de um novo padrão político que estrutura a civilização: o da possibilidade de que o campo possa se instalar em qualquer lugar e em relação a qualquer pessoa ${ }^{11}$. As periferias subdesenvolvidas, as penitenciárias brasileiras ${ }^{12}$, o setor de imigração dos aeroportos.

\section{As ditaduras latino-americanas}

É a partir deste cenário: da política do campo, da seleção do inimigo objetivo, da burocrática e técnica eliminação, da negação do crime dentro do crime, que se deve situar as ditaduras latino-americanas da segunda

10 Para Agamben a relação política originária é demarcada pelo estado de exceção, no qual predomina, sem intermediações, o poder do soberano sobre a vida nua, despida de qualificativos jurídicos e institucionais. Quem está nesta zona está fora da lei, foi abandonado pela lei, não encontra identificação possível dentro das estruturas tradicionais do Estado Nação. Os casos mais emblemáticos de aparição dessa "vida nua" são os apátridas, os refugiados e os internos dos campos de concentração. Contudo, sua aparição se dissemina visivelmente para outros espaços, nos quais os direitos e os atributos de nacionalidade e cidadania já não valem nada e são impotentes para evitar a completa descartabilidade das pessoas que estão nesses lugares, como é o caso das periferias subdesenvolvidas e das penitenciárias brasileiras. Ver: AGAMBEN, Giorgio. Homo Sacer: o poder soberano e a vida nua I. Belo Horizonte: UFMG, 2004.

11 AGAMBEN, Giorgio. Homo Sacer: o poder soberano e a vida nua I. Belo Horizonte: UFMG, 2004. p. 182-186. Já dizia Walter Benjamin em sua Tese oitava: "A tradição dos oprimidos nos ensina que o 'estado de exceção' em que vivemos é na verdade a regra geral" (BENJAMIN, Walter. Sobre o conceito da história. In: BENJAMIN, Walter. Magia e técnica, arte e política - ensaios sobre literatura e história da cultura - Obras escolhidas, I. 7. ed. Tradução de Sérgio Paulo Rouanet. São Paulo: Brasiliense, 1994. [Obras escolhidas, v. 1]. p. 226).

12 Hannah Arendt dizia que tudo o que queria aquele que perdeu a nacionalidade era tornarse um criminoso, pois assim ao menos estaria inserido no ordenamento jurídico e seria garantido pelas normas processuais penais. Assim, o "mesmo homem que ontem estava na prisão devido à sua mera presença no mundo, que não tinha quaisquer direitos e vivia sob ameaça de deportação, ou era enviado sem sentença e sem julgamento para algum tipo de internação por haver tentado trabalhar e ganhar a vida, pode tornar-se um cidadão completo graças a um pequeno roubo. Mesmo que não tenha vintém, pode agora conseguir advogado, queixar-se contra os carcereiros e ser ouvido com respeito. Já não é o refugo da terra: é suficientemente importante para ser informado de todos os detalhes da lei sob a qual será julgado. Ele torna-se pessoa respeitável" (ARENDT, op. cit., p. 320). Provavelmente, Hannah Arendt não seria tão incisiva em sua assertiva se ela houvesse conhecido o atual sistema penitenciário brasileiro, com suas prisões fétidas e desumanas, mais parecendo um depósito de gente ou ainda o sanatório no qual os novos cegos de Saramago, no seu Ensaio sobre a Cegueira, são confinados. 
metade do século XX. Foram milhares e milhares de mortos, desaparecidos, torturados, perseguidos, seqüestrados, banidos e exilados. Uma vez rotuladas como comunistas ou subversivas as pessoas entravam imediatamente naquela zona de indistinção na qual não existem direitos ou garantias.

É preciso ter claro também que o próprio continente sul-americano se estrutura sobre um genocídio que antecedeu em séculos o holocausto da Segunda Guerra Mundial, ainda que naquele contexto não houvesse o refinamento técnico e burocrático que a sociedade industrial trouxe. Quando Cortez entrou no território asteca em 1519 havia cerca de 25.000.000 habitantes. Oitenta anos mais tarde restaram apenas cerca de $1.000 .000 \mathrm{de}$ habitantes ${ }^{13}$. No Brasil, centenas de etnias indígenas foram eliminadas. Quando os portugueses chegaram ao território brasileiro havia cerca de 1.300 línguas indígenas diferentes, hoje há cerca de 170. Estima-se que a proporção de extermínio dos índios brasileiros, levando-se em conta o intervalo entre a chegada de Cabral e os dias atuais, seguiu a mesma proporção de 25 para 1 que se teve em apenas um século entre os Astecas ${ }^{14}$.

Embora o número de mortos nas ditaduras latino-americanas da segunda metade do século XX não seja tão elevado quando o dos campos de concentração da Segunda Guerra Mundial ou até mesmo o da hecatombe indígena ${ }^{15}$, tais regimes de exceção, em suas práticas e contextualização política se alojaram no rastro de continuidade instalado pelos totalitarismos e barbáries do século passado.

13 Dados trazidos por Leonardo Boff em: BOFF, Leonardo. Inquisição: um espírito que continua a existir. Prefácio. In: EYMERICH, Nicolau. Manual dos inquisidores. Comentários de Francisco Peña. Trad. Maria José Lopes da Silva. 2. ed. Rio de Janeiro: Rosa dos Tempos; Brasília: Fundação Universidade de Brasília, 1993. p. 26.

14 Segundo dados de Darcy Ribeiro em: RIBEIRO, Darcy. O povo brasileiro: a formação e o sentido do Brasil. 2. ed. São Paulo: Cia. das Letras, 1996. p. 142.

15 É preciso ponderar, ainda, que as ações de barbárie e destruição perpetradas pelas ditaduras do Cone-Sul aconteceram em poucos anos, enquanto o extermínio indígena se desenrolou por séculos. Na Argentina (1976-1983) estima-se em cerca de 30 mil o total de mortos e desaparecidos; no Uruguai (1973-1985) em torno de 400; no Chile (1973-1990) há mais controvérsia sobre essas cifras, oscilando a estimativa em torno de 3.000 a 10.000 mortos e desaparecidos; no Brasil (1964-1988), segundos dados oficiais fornecidos pela Comissão Especial de Mortos e Desaparecidos Políticos, foram 353 as vítimas fatais do regime. Importa assinalar que um número muito maior de pessoas foram presas, torturadas, perseguidas, impedidas de trabalhar, exiladas e banidas, mas que não chegarem a morrer diretamente pela ação repressora. Ver esses dados em: BRASIL. Secretaria Especial dos Direitos Humanos. Comissão Especial sobre Mortos e Desaparecidos Políticos. Direito à verdade e à memória. Brasília: Secretaria Especial dos Direitos Humanos, 2007. A publicação e o lançamento deste livro no ano de 2007, em uma grande solenidade ocorrida no Palácio do Planalto, com as presenças do Presidente da República, Luis Inácio Lula da Silva, o Ministro da Defesa, Nelson Jobim, a Ministra-Chefe da Casa Civil, Dilma Roussef e o Ministro da Secretaria Especial dos Direitos Humanos da Presidência da República, Paulo Vannuchi, representou um avanço significativo do Brasil no resgate da sua memória política. O nome do livro já diz tudo. A obra, que demarca a conclusão dos trabalhos da Comissão Especial dobre Mortos e Desaparecidos Políticos pode ser consultada no seguinte endereço eletrônico: http://www.presidencia.gov.br/ estrutura_presidencia/sedh/.arquivos/livrodireitomemoriaeverdadeid.pdf 
Todo um aparato técnico de informações e ações organizadas foi montado e colocado a serviço de crimes em massa como: prisões arbitrárias sem direito a qualquer contraditório ou garantia; torturas e sevícias cruéis que deixaram seqüelas permanentes ou resultaram em mortes; seqüestros de crianças, pais, mães e filhos; assassinatos e desaparecimentos ${ }^{16}$; monitoramentos e ameaças constantes que resultavam em prisões e mortes; banimentos e pessoas compelidas ao exílio; a descartabilidade de qualquer garantia ou qualificativo jurídico.

Os governos ditatoriais latino-americanos nesse período possuíam polícias políticas e uma verdadeira rede de informações e operações conjuntas destinadas a prender e eliminar qualquer um que fosse suspeito de ser integrante da resistência ao regime de exceção. A conhecida Operação Condor, idealizada pelo Coronel Manuel Contreras, chefe da DINA (a polícia política de Pinochet), estendeu seus tentáculos por todo o continente, prendendo, matando e seqüestrando pessoas à revelia das fronteiras e dos sistemas jurídicos ${ }^{17}$.

16 No livro Direito à verdade e à memória é esclarecida e detalhada a prática do desaparecimento: "O desaparecimento de presos políticos foi moeda corrente na América Latina dos anos 70, principalmente no Cone Sul. Essa prática consistia em seqüestrar e fazer sumir opositores políticos dos regimes ditatoriais. No Brasil, o processo não foi diferente. Com o desaparecimento, não havia como acionar qualquer dispositivo legal para tentar salvar a vida das vítimas. Não havia vestígios, nem provas. Em muitos casos comprovados, a pessoa desaparecida permaneceu semanas ou meses em local incerto, sendo torturada por seus algozes. Assim, os órgãos de repressão podiam dispor sobre a vida e a morte dos presos políticos. Não necessitavam de nenhuma justificativa para seus atos. Prendiam, torturavam, executavam e faziam desaparecer os corpos das vítimas, sem dar satisfação a tribunais, advogados, familiares, amigos e a nenhum setor da sociedade civil. As próprias leis inconstitucionais do regime eram violadas rotineiramente. A perpetuação do sofrimento dos familiares e a incerteza sobre o paradeiro de seus entes queridos levaram a uma situação de prolongada insegurança. Foi uma outra forma de tortura permanente, levada a cabo pelo Estado policial. A CEMDP computou, como saldo de suas investigações, cerca de uma centena e meia de desaparecidos políticos. Muitos deles foram vistos em dependências policiais por outros presos, que testemunharam sobre sua prisão e tortura. De outros não se têm notícias, nem das suas passagens por prisões. Eram, quase sempre, ativistas políticos notoriamente perseguidos pelos órgãos de segurança. Vários estavam submetidos a processos judiciais. Seus últimos contatos foram com companheiros de suas organizações. Depois, sumiram. Nunca mais foram vistos" (Ibidem, p. 49-50).

17 Foi lançado no ano de 2008 um importante documentário dirigido pelo cineasta Roberto Mader, intitulado Condor, que explica o contexto da operação e contém, inclusive, entrevista inédita com Contreras. Situando de modo mais específico a estrutura coesa e organizada da polícia política no Brasil, o livro Direito à verdade e à memória registra que: "Pelo menos entre 1969 e 1976, a estrutura do sistema repressivo adquiriu o formato de uma ampla pirâmide, tendo como base as câmaras de interrogatório e, no vértice, o Conselho de Segurança Nacional. O SNI tinha sido criado em 13 de junho de 1964 para recolher e processar todas as informações de interesse da segurança nacional. Seu comandante, com status de ministro, mantinha encontros diários com o presidente da República e tinha uma grande influência sobre as decisões políticas do governo. Tanto que, desse órgão, saíram dois presidentes do ciclo militar, o general Emílio Garrastazu Médici e o general João Baptista Figueiredo. 
A prática dos campos de concentração também se repetiu nas ditaduras do Cone-Sul: o Estádio Nacional e a Villa Grimaldi no Chile; os porões dos presídios e das celas do DOPS, o presídio Tiradentes e as demais prisões políticas no Brasil, bem como as bases militares brasileiras na Região do Araguaia; os campos El Vesubio e La Perla na Argentina; o presídio Libertad no Uruguai. Importa, enfim, perceber que o processo de desumanização e de extermínio era acionado pela atribuição do rótulo de "subversivo", aplicado tanto a militantes políticos de esquerda como a qualquer um que pudesse ostentar idéias e atitudes consideradas "esquerdistas", especialmente as de oposição ao regime.

\section{Cultura e barbárie}

Mesmo antes de que Auschwitz e as ditaduras do Cone-Sul viessem a ser conhecidos pelo mundo, Walter Benjamin já dizia, em suas Teses sobre o conceito de história ${ }^{18}$, que: "Nunca houve um monumento da cultura que não fosse também um monumento da barbárie"19.

Tal constatação exige um novo conceito de história que reconheça essa barbárie, e não a história triunfante e impiedosa do progresso, que contabiliza

Apesar do grande aparato montado, o serviço de inteligência não conseguiu responder com eficiência às expectativas do governo num primeiro momento. Para melhorar a eficácia repressiva, surgiu a necessidade de uma integração completa entre os organismos da repressão, ligados aos ministérios do Exército, da Marinha e da Aeronáutica, à Polícia Federal e às polícias estaduais. Em São Paulo, foi montada, em 1969, uma operação piloto que visava a coordenar esses serviços, chamada Operação Bandeirante (OBAN). Não era formalmente vinculada ao II Exército, mas estava, de fato, sob a chefia de seu comandante, o general Canavarro Pereira. A OBAN foi composta de efetivos do Exército, da Marinha, da Aeronáutica, da Polícia Política Estadual, do Departamento de Polícia Federal, da Polícia Civil, da Força Pública, da Guarda Civil e até de civis paramilitares.

A experiência da OBAN como centralizadora das ações repressivas em São Paulo foi aprovada pelo regime militar, que resolveu estender seu formato a todo o País. Nasceu então o Destacamento de Operações de Informações/Centro de Operações de Defesa Interna, lembrado ainda hoje pela temível sigla DOI-CODI, que formalizou no âmbito do Exército um comando englobando as três Armas.

Com dotações orçamentárias próprias e chefiado por um alto oficial do Exército, o DOI-CODI assumiu o primeiro posto na repressão política no país. No entanto, os Departamentos de Ordem Política e Social (DOPS) e as delegacias regionais da Polícia Federal, bem como o Centro de Informações de Segurança da Aeronáutica (CISA) e o Centro de Informações da Marinha (CENIMAR) mantiveram ações repressivas independentes, prendendo, torturando e eliminando opositores.

Esse gigantesco aparelho repressivo chegou a atuar também fora do país. Em 1972, deixou sua marca na Bolívia, após o golpe que derrubou Juan José Torres; em 1973, no Chile e no Uruguai; e em 1976, na Argentina. Essa expansão tentacular foi relatada por vários exilados submetidos a interrogatórios por agentes brasileiros quando presos naqueles países. Os agentes brasileiros explicavam sua presença no exterior como parte de uma missão para treinar em técnicas de interrogatório e tortura seus colegas bolivianos, chilenos, argentinos e uruguaios" (Ibidem, p. 23).

18 Este teria sido o último texto que escreveu antes de se suicidar em 1940, acuado pela polícia nazista, sem meios de cruzar a fronteira entre a França e a Espanha.

19 BENJAMIN, op. cit., p. 225. 
sua destruição como um custo aceitável da sua marcha incessante. Disse Benjamin: "Todos os que até hoje venceram participam do cortejo triunfal, em que os dominadores de hoje espezinham os corpos dos que estão prostrados no chão"20.

A grande tentação do projeto metafísico e também do chamado bom senso, alerta Jeanne Marie Gagnebin, é o de querer recobrir tudo com palavras e dobrar tudo às regras da apropriação racional e lingüística do sujeito ${ }^{21}$. A linguagem pode ser suficiente na coerência interna do discurso, mas quando se defronta com a história e com o sofrimento dos mortos e vencidos, ela encontra o seu limite. É justamente neste limiar que a linguagem pode ser mais verdadeira, quando ela reconhece sua própria falta. Afinal, como descrever o indescritível? Como compreender o incompreensível? Como contar o inenarrável? Mas, por outro lado, como não contar? Como ignorar? A indiferença é praticamente uma cumplicidade.

É por isto que o resgate da dignidade humana passa, antes de tudo, pela memória, por um direcionamento da ação que esteja comprometido com o conhecimento do passado de dor, enfim, por uma história dos excluídos e dos vencidos, que possa redimir a humanidade da sua fria indiferença e prevenir a ação política de continuar azeitando a máquina do progresso em sua inclemência.

\section{História e memória}

O projeto historiográfico de Benjamin lança o olhar para as vítimas que ficaram pelo caminho, combate o seu esquecimento, agarra-se firmemente nas "arestas" e "asperezas" para escapar ao efeito nivelador da história. A imagem deste projeto é apresentada pelo próprio autor em sua Tese nona sobre o conceito de história. Trata-se do Angelus Novus, quadro de Paul Klee, pintor suíço contemporâneo de Benjamin. Eis como Benjamin descreve esta imagem:

Há um quadro de Klee que se chama Angelus Novus. Representa um anjo que parece querer afastar-se de algo que ele encara fixamente. Seus olhos estão escancarados, sua boca dilatada, suas asas abertas. O anjo da história deve ter esse aspecto. Seu rosto está dirigido para o passado. Onde nós vemos uma cadeia de acontecimentos, ele vê uma catástrofe única, que acumula incansavelmente ruína sobre ruína e as dispersa a nossos pés. Ele gostaria de deter-se para acordar os mortos e juntar os fragmentos. Mas uma tempestade sopra do paraíso e prende-se em suas asas com tanta força que ele não pode mais fechá-las. Essa tempestade o impele irresistivelmente para o futuro, ao qual ele vira as costas, enquanto o amontoado de ruínas cresce até o céu. Essa tempestade é o que chamamos progresso ${ }^{22}$.

20 Ibidem.

21 GAGNEBIN, Jeanne Marie. História e narração em Walter Benjamin. 2. ed. São Paulo: Perspectiva, 2004. p. 108.

2 BENJAMIN, op. cit., p. 226. 
A figura do anjo traz, ao mesmo tempo, a idéia de salvação e de fraqueza, de redenção e de impotência, de liberdade e de aprisionamento. O olhar do anjo é o olhar das vítimas da história, horrorizado diante das ruínas, pois, para ele, os escombros são o resultado de um evento único, tão singular quanto a particularidade irrepetível das suas vítimas. As ruínas não são simplesmente a justificativa e o custo da marcha do progresso. A história aqui interrompe a história como cadeia de acontecimentos, a história concebida tanto pela visão iluminista como pela socializante. A fraqueza do anjo diante da tempestade do progresso não significa apenas a impotência de um único momento perdido frente ao cortejo épico da história oficial, ela mostra que é só através dos desvios, das dúvidas e das hesitações é que algo de diferente pode surgir da indistinção monolítica e totalitária da história sem saltos e sem rupturas ${ }^{23}$. É por este desvio que o instante, o momento da ruptura, cintila em toda a sua intensidade. Por isto o anjo está de costas para o futuro, para não perder o presente, aquela qualidade do agora que resulta de um passado renovado, não de uma repetição mecânica.

Como bem destaca Jean Marie Gagnebin, a palavra chave da concepção de história de Benjamin é interrupção (Unterbrechung) ${ }^{24}$. É preciso "fazer explodir o continuum da história", interromper o tempo linear e concatenado da história sem brechas, fazendo saltar a intensidade do instante. Percebese nos escritos de Benjamin uma atenção ao singular de cada momento e de cada pessoa, na tentativa de contraposição à voragem da história como progresso, que mergulha o singular no esquecimento e projeta o presente em uma repetição, evitando que ele se transforme em momento político, de ação, fruto do conhecimento de um passado renovado.

É preciso não confundir o empenho de Benjamin em prol de uma história dos vencidos, dos excluídos e das vítimas com a tentativa de reescrever os livros de história, ou seja, com a apresentação de uma outra versão da história que agora conte a epopéia dos escravos, camponeses, proletários, mortos, desaparecidos, conquistados e perseguidos. Não se trata, assim, ao contrário do que pensaram muitos marxistas inclusive, de apresentar uma história alternativa que, ao final das contas, teria as mesmas características da história linear: uma concatenação causal entre os fatos apresentados e um desenrolar contínuo. Uma tal pretensão perde o essencial e incorre no mesmo erro da história do progresso.

¿3 É o que de modo muito perspicaz foi registrado por Jean Marie Gagnebin. Ao comentar a Tese Segunda de Benjamin, que fala da "fraca força messiânica" que cabe à cada geração no afã do encontro com as outras que a precederam, assinala que "somente nossa fraqueza é messiânica, que é em nossas hesitações, em nossas dúvidas, em nossos desvios, que pode ainda se insinuar o apelo messiânico, ali, enfim, onde renunciamos a tudo preencher para deixar que algo de outro possa dizer-se. Violência, portanto, mas violência que não podemos usar segundo o nosso bem-querer, pois ela ameaça, justamente, o querer e a soberania da intenção, sua ambição de previsões sem falhas" (GAGNEBIN, op. cit., p. 98).

24 Ibidem, p. 96. 
A história possui em Benjamin um papel político e não meramente descritivo. O passado surge no presente para que ali se tome uma decisão, que deve ser consciente da sua fragilidade, tanto no sentido de que é humanamente impossível uma memória que abarque todas as injustiças e barbáries ${ }^{25}$, como no sentido de que através dessa fraqueza é que se rompe com a força da história linear.

Ao tempo vazio da historiografia, no qual o mesmo sempre retorna, opõese um tempo pleno, no qual o outro pode emergir ${ }^{26}$. Este outro, contudo, vem de uma cuidadosa rememoração do passado. Surge aqui o papel fundamental da memória, de uma memória perigosa. Escreve Benjamin em sua Tese Sexta: "Articular historicamente o passado não significa conhecê-lo 'como ele de fato foi'. Significa apropriar-se de uma reminiscência, tal como ela relampeja no momento de um perigo" ${ }^{27}$. Sim, esta memória é perigosa, pois, logo de saída, ela denuncia que o presente se assenta sobre uma montanha de cadáveres e de ruínas. Ela também é perigosa porque expõe aquele que recorda a um novo sofrimento. $\mathrm{E}$, por fim, ela é perigosa, pois reacende uma batalha hermenêutica sobre a significação do passado ${ }^{28}$.

\section{A ditadura militar e a batalha hermenêutica}

A batalha hermenêutica pela significação do passado é algo visível no contexto político brasileiro. Em especial com relação aos episódios viven-

25 Uma memória que dê conta disto só pode ser uma memória divina, pondera Reyes Mate invocando texto de Horkheimer (MATE, op. cit., p. 273). Ter esta memória no horizonte significa admitir a existência de uma alteridade absoluta, significa renunciar ao papel totalizante do sujeito no seu senhorio racional e lingüístico.

26 Estas duas noções diferentes de tempo demarcam duas identidades distintas que se concentram em cada pessoa. 0 sujeito histórico não se confunde com o constante retorno e afirmação de um "eu", ele surge em uma esfera que não pode ser totalmente voluntária. Assim como Marcel Proust, segundo relata em No caminho de Swan (Tradução de Mário Quintana. 2. ed. Rio de Janeiro: Globo, 1956), abre-se à erupção de lembranças involuntárias ao experimentar a madeleine (pequeno biscoito francês) com chá, o tempo pleno surge de um deixar brotar as lembranças, mas sem que se caia em um particularismo. A dimensão do involuntário, diz Benjamin além de Proust, indica uma dimensão social, coletiva, a ser recuperada no presente da ação política e consciente que pára o decurso do tempo. Tratase de uma identidade que se afirma a cada instante, que surge sempre como outra, e que, por isto mesmo, pode deixar que o outro surja, contrapondo-se à identidade que vê no tempo apenas a reafirmação de si mesma. Essas duas espécies de identidade foram trabalhadas por Paul Ricoeur (O si-mesmo como um outro. Tradução de Lucy Moreira César. Campinas: Papirus, 1991): a identidade-mesmidade e a identidade-ipseidade. Jean Marie Gagnebin chama atenção para a proximidade entre o estudo de Ricoeur e o sujeito histórico Benjaminiano (GAGNEBIN, op. cit., p. 75-76). Em outro artigo, tive a oportunidade de explorar as noções de Ricoeur para questionar a noção de sujeito de direito. Ali tais categorias estão mais detalhadas e desenvolvidas. Ver: SILVA FILHO, José Carlos Moreira da. Pessoa humana e boa-fé objetiva nas relações contratuais: a alteridade que emerge da ipseidade. In: SILVA FILHO, José Carlos Moreira da; PEZZELLA, Maria Cristina Cereser (orgs.). Mitos e rupturas no direito civil contemporâneo. Rio de Janeiro: Lumen Juris, 2008. p. 291-323.

27 BENJAMIN, op. cit., p. 224.

28 MATE, op. cit., p. 278. 
ciados durante a ditadura militar (tema mais específico do presente texto). A anistia brasileira, datada de 1979, embora tenha surgido pela pressão de movimentos sociais que se opunham ao regime ditatorial e lutavam pela abertura política, foi conduzida e chancelada pelo próprio regime militar, o que impediu que processos mais incisivos de resgate da memória política pudessem acontecer, nos moldes do que se viu, por exemplo, tanto no Chile quanto na Argentina. Nestes países, houve processos penais e condenações por tortura e crimes contra a humanidade dos agentes e governantes envolvidos, em especial o General Pinochet e o General Videla ${ }^{29}$.

No Brasil, não houve até o presente momento, um processo semelhante ${ }^{30}$. Desde o início da chamada distensão, ficou clara a batalha hermenêutica. É o que se verificou quando se entendeu (e ainda se entende), por exemplo, que a expressão "crimes conexos" que consta na Lei de Anistia de 1979 indicava a anistia (no sentido próprio de esquecimento) de torturadores e assassinos a serviço do regime. Há uma grande resistência, por parte dos setores mais diretamente ligados à repressão militar (em especial militares da reserva e políticos que defenderam o regime) em se admitir a ocorrência das torturas e dos desaparecimentos forçados. Muitos se referem ao golpe militar como uma "revolução", na tentativa de legitimar o regime autoritário

29 Contudo, como bem assinala Rodrigo Stumpf González, há também nestes países o risco de um mal esquecimento do passado autoritário que poderá reforçar eventualmente o retorno de tais práticas (GONZÁLEZ, Rodrigo Stumpf. Direitos humanos na América Latina hoje: heranças de transições inconclusas. In: KEIL, Ivete, VIOLA, Sólon e ALBUQUERQUE, Paulo [orgs.]. Direitos Humanos: alternativas de justiça social na América Latina. São Leopoldo: UNISINOS, 2002. p. 169-184).

30 Analisando o processo de transição democrática brasileira e indicando o direito da sociedade em ter acesso às informações sobre o seu passado para que ela possa reconstruí-lo, Rodrigo Stumpf González observa que: "No caso brasileiro deu-se uma 'reconciliação nacional' pelo alto, através de um novo pacto de elites e da inércia dos setores atingidos para mobilizar a possibilidade de punições. A transição pactuada afastou da agenda a discussão acerca dos crimes da ditadura. Diferentemente da Argentina, não houve uma suspensão das investigações ou limitação de julgamentos. Simplesmente não se permitiu que investigações sérias ocorressem. Inclui-se aqui também casos posteriores à lei de anistia, como a colocação de uma bomba na sede nacional da $\mathrm{OAB}$ e a explosão do Rio-Centro. Por outro lado, esta decisão de "deixar para traz o passado" não partiu da população, como no plebiscito uruguaio, que mesmo que tenha ocorrido sob pressão, foi uma forma de consulta democrática. A busca de respostas acerca da responsabilidade e das circunstâncias das mortes dos perseguidos pela ditadura, bem como dos torturados e presos sobreviventes tem sido vista como um direito perseguido pelas vítimas e seus familiares. No entanto, existe um direito, que 0 do conjunto da população, representada pelo Estado, neste caso, de tomar conhecimento destes fatos.

Se por uma decisão política a possibilidade de punição dos agressores foi limitada pela lei de anistia de 1979, nada impede a divulgação dos fatos e o nome dos responsáveis. Se a sanção penal foi excluída, o julgamento da opinião pública é necessário, se queremos construir as bases de uma democracia duradoura e que tenha o respeito aos direitos humanos como um de seus pilares. Por outro lado, a questão mantém a sua atualidade, aos constatarmos que prisões ilegais e tortura não são fatos do passado, mas continuam a ocorrer contra presos comuns" (Ibidem, p. 178). 
ocorrido. Outro exemplo diz respeito aos desaparecimentos. A Lei de 1979 utiliza, ainda, a expressão "ausentes", oriunda da dogmática jurídico-civilista, para se referir aos desaparecidos, o que leva à conotação de uma morte presumida e não de um assassinato cujo cadáver não é encontrado. Quando nas fichas da DOPS dizia-se que alguém foi "interrogado" ou "prestou esclarecimentos", é preciso saber que ele foi, na verdade, torturado.

Mais recentemente, com a edição da Lei 10.559/2002, que regulamenta o direito constitucional à indenização para os perseguidos políticos pela ditadura militar e atribui a função de decidir sobre as indenizações à Comissão de Anistia do Ministério da Justiça, alguns setores da sociedade, apoiados por parcelas expressivas da mídia impressa e televisiva, passaram a chamar essa indenização de "bolsa ditadura", adotando um flagrante tom depreciativo. Militantes políticos eram e são chamados de "terroristas", torturadores eram e são chamados de "patriotas".

Além dos episódios ocorridos durante a ditadura militar, a sociedade brasileira continua, visivelmente, a colocar em prática o rótulo do inimigo objetivo a outros setores da população, como é o caso dos jovens da periferia que passam a ser rotulados de "traficantes", atraindo para si toda sorte de procedimentos policialescos que desconhecem olimpicamente qualquer garantia de proteção à pessoa humana, no que são, inclusive, apoiados por setores expressivos da população, sequiosa em responder o problema da segurança com mais violência e preconceito. Isto sem mencionar o problema da criminalização dos movimentos sociais e do desrespeito às culturas indígenas. Antes de se questionar a "violência" das manifestações dos movimentos sociais, é preciso questionar a violência, que para grande parte das pessoas parece algo natural, em relegar milhares e milhares de pessoas à fome, à ausência de moradia, ao desemprego e à ação preconceituosa das forças policiais do país.

Por outro lado, várias ações têm assumido destaque no esforço de resgatar a memória política do Brasil com relação à ditadura recente em que se viveu. Desde 2007, a Comissão de Anistia do Ministério da Justiça tem atuado não somente no sentido de apreciar e julgar os requerimentos de anistia política e indenizações, mas, igualmente, na implementação de um projeto educativo que se desdobra em duas direções: a realização das Caravanas da Anistia e a construção do Memorial da Anistia. As Caravanas da Anistia têm percorrido o Brasil no intuito de provocar a discussão e o resgate da memória sobre o período ditatorial mediante julgamentos públicos, palestras, filmes, debates e outras atividades. Já o Memorial da Anistia Política pretende ser um espaço destinado a arquivar documentos do e sobre o período, bem como documentários, filmes, espaços de pesquisa e ensino, entre outros, tendo já sido assinada pelo Ministro da Justiça, em maio de 2008, a Portaria que cria o Memorial.

Outra importante iniciativa neste sentido foi a decisão do Governo Federal de centralizar no Arquivo Nacional documentos da ditadura militar 
guardados atualmente em arquivos de órgãos federais e estaduais. O objetivo é centralizar informações das divisões do extinto Serviço Nacional de Informações (SNI) nos ministérios e estatais e colocá-las à disposição do cidadão em um banco de dados que poderá ser acessado pela internet.

O projeto de criação do centro foi batizado de "Memórias Reveladas". Em 2005, o Decreto 5.584 determinou que instituições federais transferissem documentos referentes à ditadura ao Arquivo Nacional, que passou a guardar dados do SNI, da Comissão Geral de Investigações e do Conselho de Segurança Nacional, que estavam nas mãos da Agência Brasileira de Inteligência, a ABIn.

Pretende-se também a implantação de uma rede de cooperação com acervos públicos de dez estados (Rio Grande do Sul, Paraná, Rio de Janeiro, São Paulo, Espírito Santo, Minas Gerais, Pernambuco, Maranhão, Sergipe e Ceará), que dispõem de dados sobre os Departamentos de Ordem Política e Social - DOPS.

Para reunir as informações, o Governo Federal determinou que os ministérios e estatais encaminhassem suas informações sobre o período ao Arquivo Nacional. Desde então, o material da instituição aumentou muito. Os ministérios das Relações Exteriores, da Saúde, da Justiça e a Polícia Federal são alguns que já mandaram documentação. As Forças Armadas, porém, ainda não enviaram os seus dados.

Outra ação que sinaliza para o resgate da memória política do país é a propositura de ação civil pública pelo Ministério Público Federal contra a União e os militares reformados Carlos Alberto Brilhante Ustra e Audir Santos Maciel, comandantes do DOI-CODI em São Paulo de 1970 a 1976. O MPF pede que ambos sejam pessoalmente responsabilizados pela tortura, morte e desaparecimento de 64 pessoas, entre elas Vladimir Herzog e Manoel Fiel Filho, e que sejam obrigados a ressarcir à União o dinheiro gasto com as indenizações respectivas. O MPF pede ainda que sejam condenados a não mais exercerem função pública. É a primeira vez que o Ministério Público no Brasil propõe uma ação civil buscando a punição de militares envolvidos com a repressão política no regime militar.

A já mencionada publicação pelo Estado brasileiro do livro Direito à verdade e à memória, bem como a contínua elaboração de filmes e documentários sobre o período da ditadura militar no país também se integram a um cenário palpável de resgate da memória política brasileira. É preciso, contudo, ter consciência de que esses fatos recentes, que visam reacender o debate sobre a ditadura no Brasil, não escondem, do mesmo modo, a existência de vastos setores da sociedade que se deixam comodamente arrastar pela idéia de uma história linear, pela necessidade de pagar o progresso com custos incalculáveis sob o ponto de vista dos grupos excluídos na sociedade, e mesmo de setores que cedem à tentação de simplesmente propor uma outra história no lugar da oficial, perdendo o que há de essencial na filosofia da história de Benjamin: a mantença de 
uma abertura constante entre o passado de exclusão e dor sem possibilidade de descrição e o presente que recupera este passado e o concretiza na ação política cujo horizonte é a redenção ${ }^{31}$.

\section{Testemunho e narração}

Admitir a história como ruptura e interrupção para que nela possa emergir a tradição dos oprimidos traz um paradoxo ${ }^{32}$ : como narrar algo descontínuo, que se dá no desvio? $\mathrm{E}$ mais do que isso: diante da experiência do sofrimento como conseguir que as palavras possam descrevê-lo? Por outro lado, é imperativo que, apesar da incomunicabilidade do sofrimento e do horror, ele seja narrado. Para narrar, contudo, é preciso testemunhar. E para que o testemunho não tenha sido em vão, é preciso que ele seja ouvido.

Em dois ensaios, Walter Benjamin dá destaque à figura do narrador. Em ambos sugere uma idéia de história como narração. No texto Experiência e pobreza, Benjamin inicia contando a parábola do velho moribundo que, no momento da sua morte, cercado pelos seus filhos, revela a eles a existência de um tesouro nos seus vinhedos. Os filhos cavam intensamente o terreno, mas nada encontram. Com a chegada do outono, porém, tendo em vista o forte trabalho de aragem da terra que acabou por ser feito na busca do tesouro, as vinhas produzem mais do que qualquer outra na região. A conclusão, explica Benjamin, é que o pai moribundo quis transmitir aos filhos uma experiência: "a felicidade não está no ouro, mas no trabalho" 33 .

Nessa parábola se apresenta um conhecimento que se apóia na transmissão da experiência, de uma tradição que une gerações em sua narrativa passada de pai pra filho. A autoridade da velhice se apresenta como a de um viajante longínquo que tem muito o que contar diante de uma audiência sequiosa por ouvi-lo e acolher sua experiência ${ }^{34}$. Benjamin constata, porém, que tal espécie de transmissibilidade experimenta o seu ocaso, e pergunta:

31 O tema da redenção em Benjamin será desenvolvido mais adiante, no último item deste artigo.

32 GAGNEBIN, op. cit., p. 99.

33 BENJAMIN, Walter. Experiência e Pobreza. In: BENJAMIN, Walter. Magia e técnica, arte e política - ensaios sobre literatura e história da cultura - Obras escolhidas, I. 7. ed. Tradução de Sérgio Paulo Rouanet. São Paulo: Brasiliense, 1994. [Obras escolhidas; v. 1]. p. 114.

34 Tolstoi, em A morte de Ivan Ilitch, conta a história de Ivan Ilitch um homem que, ao longo de toda a sua vida se deixou pautar pelas conveniências, hierarquias e burocracias da vida social. Magistrado que rapidamente galgou cargos em sua carreira, Ivan Ilitch tratou sua família com distanciamento, evitou o contato com estranhos, catalogou suas relações nos escaninhos das posições sociais e tratou seus réus como casos cuja solução residia no preciso domínio conceitual e técnico da dogmática jurídica. Tudo parecia ir às mil maravilhas até que se descobre portador de uma doença mortal e, ao consultar um médico famoso, se vê tratado por ele exatamente como tratava as pessoas em seus processos: como casos impessoais e estatísticos. Confinado no isolamento do seu quarto Ivan Ilitch espera a morte, tentando justificar sua vida como algo maravilhoso, como algo que valeu à pena. Contudo, não consegue afastar totalmente a sensação de que sua vida não se ligou a nada de realmente importante e bom, e que a pior violência é não admitir estar vivendo naquele momento a experiência do sem sentido de sua existência, que se torna clara diante da morte. E à sua 
Quem encontra ainda pessoas que saibam contar histórias como elas devem ser contadas? Que moribundos dizem hoje palavras tão duráveis que possam ser transmitidas como um anel, de geração em geração? Quem é ajudado, hoje, por um provérbio oportuno? Quem tentará, sequer, lidar com a juventude invocando sua experiência? ${ }^{35}$

O império da técnica e da sua objetividade totalizante emudeceu os contadores de histórias. Os combatentes que retornaram da Primeira Guerra Mundial, diz Benjamin, voltaram mudos, sem experiências que possam ser comunicadas. "Porque nunca houve experiências mais radicalmente desmoralizadas que a experiência estratégica pela guerra de trincheiras, a experiência econômica pela inflação, a experiência do corpo pela fome, a experiência moral pelos governantes" ${ }^{36}$. Trata-se de uma pobreza de experiência na qual a sociedade está toda mergulhada.

volta não havia ninguém para partilhar esta experiência decisiva, todos negavam até oúltimo instante que ele estava morrendo, a mulher, seus filhos, seus conhecidos. 0 único que não negava era Gerassim, o criado simples e solidário que dele cuidava. Conta Tolstoi, desvendando os pensamentos do seu personagem, que o "horrível, terrível ato de sua morte, ele via, estava sendo reduzido por aqueles que o rodeavam ao nível de um acidente fortuito, desagradável e um pouco indecente (mais ou menos como se comportam com alguém que entra em uma sala de visitas cheirando mal), e agiam assim em nome do mesmo decoro ao qual ele próprio subjugara-se a vida inteira. Notava que ninguém se compadecia dele porque ninguém estava com disposição nem mesmo de pensar em sua situação. Gerassim era a única pessoa que entendia o que ele estava passando e lamentava por ele, e por isso Ivan Ilitch só sentia-se bem em sua presença". E quando Ivan Ilitch chega perto da morte, dias antes de entregar seu último suspiro, ele percebe que pior que a dor física eram seus sofrimentos mentais. "Ocorreu-lhe, pela primeira vez, o que lhe tinha parecido totalmente impossível antes - que ele não teria vivido como deveria. Veio-lhe à cabeça a idéia de que aquela sua leve inclinação para lutar contra os valores das classes altas, aqueles impulsos de rebeldia que mal se notavam e que ele havia tão bem aplacado talvez fossem a única coisa verdadeira, e o resto todo, falso. E suas obrigações profissionais e a retidão de sua vida e sua família e sua vida social tudo falso e sem sentido. Tentou defender essas coisas a seus próprios olhos e subitamente deu-se conta da fragilidade do que estava defendendo. Não havia o que defender". A partir deste momento de ruptura e despertar, Ivan Ilitch debatese e grita por dias, extravasando uma fúria desesperada, até que horas antes de falecer, finalmente aceita sua condição, reconhece que sua vida fora empenhada em coisas sem valor, mas exatamente neste ponto, no momento em que morre, percebe que tudo pode ser consertado na autêntica experiência deste último momento, no qual pode aflorar todo o valor que ainda resta em seu âmago, compadecendo-se das lágrimas do seu filho e da sua mulher. "Abriu os olhos e viu seu filho. Sentiu pena dele. Sua mulher se aproximou, olhou para ela. Ela olhava-o fixamente de boca aberta, as lágrimas escorrendo no nariz e nas bochechas e uma expressão de desespero no rosto. Sentiu pena dela também. 'Sim, sou um sofrimento para eles', pensou. 'Eles lamentam um pouco, mas vai ser muito melhor para eles quando eu morrer!' Quis dizer-lhes isso, mas não tinha forças para falar. 'Além do mais, para que falar? Resta-me agir', pensou. Indicou com o olhar seu filho e disse para a mulher: - Leve-o daqui...sinto muito por ele. Lamento por você também. - Tentou dizer 'perdoe-me', mas não conseguiu terminar e, fraco demais para tentar outra vez, acenou com a mão, sabendo que quem estivesse interessado entenderia" (TOLSTÓI, Leon. A morte de Ivan Ilitch. Tradução de Vera Karam. Porto Alegre: L\&PM, 2002).

36 BENJAMIN, Experiência e pobreza, p. 114.

36 Ibidem, p. 115. 
Diante desse diagnóstico, conclui Benjamin em outro texto chamado $O$ narrador, que "a arte de narrar está em vias de extinção" ${ }^{37}$. A fonte de todos os narradores é exatamente o que entra em declínio na era da reprodutibilidade técnica ${ }^{38}$ : a experiência passada de pessoa para pessoa, a construção artesanal de uma história que passa de boca em boca, de um relato que não tem a pretensão de oferecer todas as interpretações e explicações, mas apenas de contar uma história ${ }^{39}$. Ao invés da narrativa, o que predomina é a informação, aquela que surge na imprensa e que aspira a uma verificação imediata. "Cada manhã recebemos notícias de todo o mundo. E, no entanto, somos pobres em histórias surpreendentes. A razão é que os fatos já nos chegam acompanhados de explicações" ${ }^{40}$. Tais explicações fecham a informação nela mesma, visto que o seu objetivo é simplesmente atender a um momento efêmero. A informação só tem valor quando é nova. A narrativa é algo muito diferente, ela se espraia no tempo, mas não na pretensão de dar conta de tudo (ao contrário do caráter explicativo da informação), e sim com o intuito de resgatar um passado, uma tradição que se torna sempre renovada. É como um conselho, diz Benjamin.

O narrador é alguém que sabe dar conselhos. A narração volta-se para uma dimensão prática. Quem ouve o relato, o faz para com ele aprender algo para o seu momento atual. "Aconselhar é menos responder a uma pergunta que fazer uma sugestão sobre a continuação de uma história que está sendo narrada"41. Aquele que se dispõe a ser aconselhado, por sua vez, necessita verbalizar a sua própria situação. A tradição resgatada na narrativa não surge para fechar-se em si mesma, qual uma peça de museu, mas sim para situar o presente. "O conselho tecido na substância viva da existência tem um nome: sabedoria" 42 .

O esfacelamento da narração é acompanhado pela dificuldade que o homem contemporâneo tem em encarar a morte (tanto a que passou com a que o espera). A morte, explica Benjamin, era algo público e exemplar que,

37 BENJAMIN, Walter. O narrador - considerações sobre a obra de Nikolai Leskov. In: BENJAMIN, Walter. Magia e técnica, arte e política - ensaios sobre literatura e história da cultura - Obras escolhidas, I. 7. ed. Tradução de Sérgio Paulo Rouanet. São Paulo: Brasiliense, 1994. [Obras Escolhidas, v. 1]. p. 197.

38 Esta é a expressão utilizada por Benjamin em outro texto muito conhecido. Ver: BENJAMIN, Walter. A obra de arte na era de sua reprodutibilidade técnica. In: BENJAMIN, Walter. Magia e técnica, arte e política - ensaios sobre literatura e história da cultura - Obras escolhidas, I. 7. ed. Tradução de Sérgio Paulo Rouanet. São Paulo: Brasiliense, 1994. [Obras Escolhidas; v. 1]. p. $165-196$.

39 Diz Benjamin que "metade da arte narrativa está em evitar explicações. (...) 0 extraordinário e o miraculoso são narrados com a maior exatidão, mas o contexto psicológico da ação não é imposto ao leitor. Ele é livre para interpretar a história como quiser, e com isso o episódio narrado atinge uma amplitude que não existe na informação" (Ibidem, p. 203).

40 Ibidem.

41 Ibidem, p. 200.

4 Ibidem. 
todavia, passou a ser cada vez mais expulsa do espaço dos vivos. "Hoje, os burgueses vivem em espaços depurados de qualquer morte e, quando chegar sua hora, serão depositados por seus herdeiros em sanatórios e hospitais" 43 .

Toda essa constatação que Benjamin faz da derrocada narrativa, cercada de um forte tom melancólico, não deve ser, contudo, entendida como a nostalgia de um passado de ouro que nunca mais voltará. Benjamin se insere e explicitamente se perfila ao lado de uma tradição narrativa contemporânea ${ }^{44}$ que denuncia a queda das narrativas antigas, a única experiência que pode ser comunicada é a impossibilidade de narrar, de transmitir a experiência. Somente na mantença do reconhecimento deste fato é que será possível uma nova narratividade, assim como uma nova relação com a morte ${ }^{45}$. Somente da aceitação da finitude, da fragilidade, enfim, da própria condição humana é que pode brotar uma história redimida, que se convença da impossibilidade de abarcar tudo com um discurso científico e nivelador, o que fica cruamente evidente diante do sofrimento e da barbárie.

A aceitação da finitude humana funda uma nova narratividade que, mesmo sabedora da impossibilidade de transmitir a experiência do sofrimento, não se furta a transmiti-la, ainda que seja através do silêncio crispado que se desvela em um nó na garganta ou em um olhar amargurado. É importante que os fatos sejam narrados pelas testemunhas, ainda que o testemunho nunca faça jus ao que aconteceu, pois é na precisão de vários acontecimentos que não foram contados e que se amontoam nas ruínas da história que se poderá sentir o sopro do que não tem expressão. A verdade será então sentida desnudando-se o coração da palavra, que é ele mesmo sem representação possível e suficiente. A "verdade é verdade para alguém". O relato converte o ouvinte em testemunha, e, para tanto, o testemunho há que ser um acontecimento ${ }^{46}$.

43 Ibidem, p. 207.

$4 \mathrm{O}$ autor de maior contundência nessa direção, ao lado de quem Benjamin expressamente se coloca, é Franz Kafka. Ver: BENJAMIN, Walter. Franz Kafka - a propósito do décimo aniversário de sua morte. In: BENJAMIN, Walter. Magia e técnica, arte e política - ensaios sobre literatura e história da cultura - Obras escolhidas, I. 7. ed. Tradução de Sérgio Paulo Rouanet. São Paulo: Brasiliense, 1994. [Obras escolhidas, v. 1]. p. 137-164. Kafka, em sua obra, denuncia o fim de uma tradição e a impossibilidade de colocar algo em seu lugar, seja Deus ou uma versão apaziguadora da história humana. Ao denunciar este nada angustiante, explica Gagnebin, Kafka não sugere a sua superação. "Não a superação do nada por um qualquer 'conteúdo' positivo, mas sim a persistente demora 'no avesso do nada', eis o que a obra de Kafka observa e, igualmente, exige de seus leitores. A 'redenção' está a esse preço". É preciso assim realizar uma "domesticação dolorosa do nada" (GAGNEBIN, op. cit., p. 68).

45 Gagnebin arrisca explicitamente tal hipótese, chamando atenção para a necessidade de que esta nova relação com a morte se dê tanto individual quanto socialmente (Ibidem, p. 65). Afirma ainda que essa nova narratividade, que emergirá de uma nova relação com a morte, é "uma atividade narradora que salvaria o passado, mas saberia resistir à tentação de preencher suas faltas e de sufocar seus silêncios" (Ibidem, p. 63).

46 MATE, op. cit., p. 191-192. 
Primo Levi conta que um pesadelo recorrente que ele e outros internos de Auschwitz tinham quando conseguiam dormir era o de reencontrar seus familiares, e outras pessoas, e contarem a elas suas experiências no campo. A reação das pessoas no sonho é a de parecerem indiferentes e nada falarem ou comentarem sobre o que foi relatado ${ }^{47}$. É como se essas pessoas se recusassem a se transformar de espectadores em ouvintes. Assim, apesar da impossibilidade de narrar, o pior pesadelo para quem testemunha e vive o sofrimento é não poder contá-lo para ninguém, é correr o risco de que ninguém tome conhecimento do suplício sofrido e a injustiça se perpetue na ignorância e em um silêncio vazio, ausente de intérpretes que possam lhe dar sentido.

A testemunha é aquela figura que recupera parte da realidade, a que ficou relegada para as ruínas da história. Recuperar a memória não significa apenas reforçar a garantia de que as ditaduras e os totalitarismos nunca mais ocorrerão. É mais do que isso. Significa fazer justiça àquelas vítimas que caíram ao longo do caminho. Fazer justiça significa dar voz aos emudecidos pela marcha amnésica do progresso; significa resistir à destruição do diverso e do plural sob a desculpa da unidade, seja ela a da soberania nacional, a do desenvolvimento econômico ou a da razão científica; significa renunciar ao frio e distante ponto de observação neutro, universal e abstrato e dar lugar ao olhar da vítima, pois este nunca é desinteressado e distante, pois este recompõe a realidade esquecida e negada, restaurando a humanidade em quem lhe dá ouvidos. O ouvinte passa a ser cúmplice da testemunha. O relato passa a ser um acontecimento.

\section{Testemunhos da ditadura militar brasileira}

A experiência na Comissão de Anistia do Ministério da Justiça brasileiro tem mostrado continuamente o quanto tudo o que se afirmou acima a respeito

47 Eis como o conta Primo Levi: "Aqui está minha irmã, e algum amigo (qual?), e muitas outras pessoas. Todos me escutam, enquanto conto do apito em três notas, da cama dura, do vizinho que gostaria de empurrar para o lado, mas tenho medo de acordá-lo porque é mais forte que eu. Conto também a história da nossa fome, e do controle dos piolhos e do Kapo que me deu um soco no nariz e logo mandou que me lavasse porque sangrava. É uma felicidade interna, física, inefável, estar em minha casa, entre pessoas amigas, e ter tanta coisa para contar, mas bem me apercebo de que eles não me escutam. Parecem indiferentes; falam entre si de outras coisas, como se eu não estivesse. Minha irmã olha para mim, levanta, vai embora em silêncio.

Nasce então, dentro de mim, uma pena desolada, como certas mágoas da infância que ficam vagamente em nossa memória; uma dor não temperada pelo sentido da realidade ou a intromissão de circunstâncias estranhas, uma dor dessas que fazem chorar as crianças. Melhor, então, que eu torne mais uma vez à tona, que abra bem os olhos; preciso estar certo de que acordei, acordei mesmo.

O sonho está na minha frente, ainda quentinho; eu, embora desperto, continuo, dentro, com essa angústia do sonho; lembro, então que não é um sonho qualquer; que, desde que vivo aqui, já o sonhei muitas vezes, com pequenas variantes de ambiente e detalhes. Agora estou bem lúcido, recordo também que já contei o meu sonho a Alberto e que ele me confessou que esse é também o sonho dele e o sonho de muitos mais; talvez de todos" (LEVI, Primo. É isto um homem? Tradução de Luigi Del Re. 2. ed. Rio de Janeiro: Rocco, 1997. p. 60). 
do testemunho é pertinente. Os requerimentos de anistia formulados por pessoas que sofreram prisões e torturas vêm, em muitos casos, acompanhados de relatos contundentes que denunciam em suas vírgulas, reticências e adjetivos a ausência de representação possível das injustiças e abusos sofridos. Tais ausências se tornam ainda mais evidentes quando tais requerentes tomam a palavra durante as sessões de julgamento dos seus requerimentos. O olhar acuado, as mãos contraídas, o nó na garganta, os suspiros e silêncios, as lágrimas, as hesitações das palavras e dos gestos, mas também, a raiva, os braços enérgicos, os brados, o tom elevado, o rosto crispado, a dureza monolítica do corpo unindo todos os membros e partes em um inabalável e único conjunto. Há também os que declamam poesias, entoam cantos e hinos, expõem sua arte em performances ou até em obras de arte.

Recentemente, na Caravana da Anistia ocorrida em Curitiba no Estado do Paraná no dia 27 de junho de 2008, o artista Júlio Manso, o mais novo dos três filhos de Ildeu Manso Vieira, conhecido jornalista paranaense e membro do Partido Comunista Brasileiro que atuou na resistência à ditadura militar e que foi preso e barbaramente torturado, executou uma bela performance artística em homenagem ao seu pai, acompanhado por imagens no telão que mostravam cartas que Ildeu Manso escreveu da prisão para os filhos e fotos que mostravam a família reunida em momentos alegres. Juntamente com a performance, Júlio apresentou a exposição intitulada "Interna Mutilação", que consiste em animais esculpidos em cera de abelha que estão presos em pequenos cubículos, com as patas cimentadas no chão e com alguns membros do corpo trocados por objetos estranhos. Eis como Júlio Manso, no libreto da exposição, explica um trabalho que busca trazer à tona as cicatrizes de quem sofreu a tortura de ter alguém querido sob tortura:

Esses objetos são referências a pedaços que nos são retirados. Fragmentos de uma vida levados a despeito de nosso desejo. Certa natureza, que nos diz que não podemos viver sós e que o vazio em breve deve ser ocupado. Neste caso, os animais de cera de abelha são recolhidos de um mundo distante, e muitos deles, longe de seus semelhantes.Normalmente o preenchimento das peças é demorado, pois o que se revela leva um bom tempo para ser reconhecido. De modo que é também uma homenagem póstuma ao meu pai, que me ensinou a arte da temperatura da mão sobre a cera para uma boa modelação. Vejo nessas esculturas de materiais deslocados o pedaço deixado pelo meu pai nos porões da ditadura: a tortura como mutilação.

Ao longo do texto explicativo de sua exposição, Júlio Manso indica quais as lembranças que motivaram algumas das peças. Eis um trecho que se refere às peças "Calendário" e "Girafa sem pernas" e depois outro que se refere à do "Anjo ateu":

Para que serve um calendário, se o tempo presente está ausente da vida plena? Passou e não levou a lugar nenhum. Os doze primeiro meses foram os mais difíceis. Eram presos políticos sem condenação. O aperto das ditaduras 
nos países vizinhos fez do tempo encarcerado um momento sem chegada. A espera pela visita nos fins de semana fazia dos encontros uma alegria e também uma choradeira. Na entrada do presídio, lá estavam nossos queridos com as mãos colocadas nas grades do segundo andar do pavilhão dos heróis, disputando um pequeno espaço para ver lá embaixo seus familiares. Muitos gritavam os nomes dos visitantes para os demais. Imagino o esforço de manter a cabeça erguida, mesmo que a girafa não tenha as pernas.

[...] Como um herói que não teve tempo para fazer riqueza, morre de câncer no intestino, preso por 29 dias, pela última vez, a tubos e aparelhos em uma UTI em Maringá, em maio de 2000.

Existem imagens que estão no nosso subconsciente. Parecem permanecer em repouso. $O$ anjo que abriga as crianças é o mesmo que olha pela humanidade, mesmo que seja um Anjo Ateu. Para um homem sem fé, só resta queimar-se com suas lágrimas.

Outra experiência que evidencia o testemunho e a narrativa com relação à ditadura militar brasileira ocorreu em setembro de 2007 e em abril de 2008, quando então a Comissão, representada por parte dos seus membros, esteve na região onde ocorreu a Guerrilha do Araguaia ${ }^{48}$, mais precisamente

48 No início dos anos 70 um grupo de 75 militantes do Partido Comunista do Brasil, o PC do B, decidiu, em face do austero regime de exceção em vigor no Brasil, se instalar no norte do país, em plena selva amazônica, na região conhecida como "bico do papagaio" (confluência dos Estados do Pará, Maranhão e Tocantins), próxima ao Rio Araguaia, para a partir dali oferecer resistência armada à ditadura militar. No início, se instalaram incógnitos na região e eram conhecidos pelos seus habitantes pelo nome de "paulistas" ou "povo da mata", estabelecendo uma relação harmoniosa com a população local, oferecendo, inclusive, serviços de saúde, fundando escolas e demais providências que o Estado brasileiro jamais havia tomado até então, sendo esta região, à época, verdadeiramente abandonada pelas instituições públicas. Uma vez que o exército descobriu a existência do foco guerrilheiro iniciou suas investidas na região. Em uma seqüência de operações secretas que se desenrolaram por cerca de dois anos (de 1972 a 1974) o exército brasileiro envolveu o maior contingente até hoje mobilizado entre as suas fileiras após a Segunda Guerra Mundial. Foram de 3 a 10 mil homens, com aviões, helicópteros, carros de combate, embarcações de guerra, pára-quedistas, e demais equipamentos para combater 75 guerrilheiros. Como 0 exército não conhecia a região, foi preciso uma infiltração na população local com vistas a se conseguir mapear as bases guerrilheiras. Neste sentido, foi fundamental a atuação do Major Curió, como ficou conhecido, ora obtendo informações mediante disfarce de empreendedor e comerciante, ora atuando diretamente na repressão física, morte e interrogatório tanto dos guerrilheiros quanto dos habitantes da região que pudessem dar alguma informação útil. As ordens dadas pelo Presidente Emílio Garrastazu Médici era a de não deixar sobreviventes. Os corpos dos guerrilheiros e guerrilheiras até hoje não foram encontrados e as Forças Armadas se negam a abrir os seus arquivos. Os oficiais que atuaram na época e que ainda vivem também se negam a dar as informações. Além dos guerrilheiros, muitos lavradores e lavradoras humildes foram torturados e tiveram suas casas e seus parcos bens destruídos. Alguns foram escravizados para servirem de guia aos militares dentro da selva, outros resolveram colaborar em busca de vantagens. A Guerrilha do Araguaia é uma verdadeira ferida aberta na história do Brasil, visto que, de todas as histórias da ditadura militar, é a que está envolta em maior segredo e mistério, e que tem voltado à cena pública nos últimos anos, o que se deve às ações judiciais movidas pelas associações de parentes e amigos das vítimas, pela atuação de órgãos do governo como a Secretaria Especial de Direitos Humanos 
em São Domingos do Araguaia, no Estado do Pará. A missão ali era tomar o depoimento de lavradores e lavradoras que ingressaram com requerimentos de indenização por perseguição política junto à Comissão de Anistia do Ministério da Justiça, visto que os processos estavam muito mal instruídos e sem informações importantes.

O sentido daquelas visitas se deu também como o marco simbólico de uma ansiedade há muito escondida na consciência pública do país, e que ali se externava no sentimento de cada um dos membros da Comissão e de outros presentes. Até então o Estado brasileiro não havia se apresentado oficialmente na região do conflito com o propósito de discutir e enfrentar diretamente o episódio da guerrilha, visto que vinha adotando uma postura radicalmente oposta: a de não admitir oficialmente o ocorrido. Foi um verdadeiro acontecimento. A Comissão de Anistia e sua comitiva, composta por Conselheiras e Conselheiros, advogados e advogadas que trabalham nos setores de apoio, jornalistas, membros de grupos como o Tortura Nunca Mais, e, ainda, membros da Secretaria de Direitos Humanos da Presidência da República, representava ali o Estado brasileiro.

A grande parte dos requerimentos vinha instruída tão-somente com um termo do depoimento testemunhal do próprio ou da própria requerente. Isto é assim principalmente pelo fato de que praticamente não existem documentos oficiais sobre a Guerrilha do Araguaia e sobre as prisões e abusos sofridos pela população local. É, portanto, um contra-senso o Estado brasileiro, agora, exigir provas documentais quanto a uma perseguição política que ele mesmo promoveu e da qual jamais permitiu que fosse produzido ou viesse à luz algum documento ou registro oficial.

De todo modo, a Comissão constatou a necessidade de aprimorar os depoimentos dos requerentes e ir diretamente ao local para fazer perguntas e ouvir os relatos, visto que a prova testemunhal no caso da Guerrilha do Araguaia, dada a ausência de outros documentos assume maior centralidade.

A oitiva dos requerentes ocorreu em um sítio da Paróquia da cidade, no qual também acontecia, em função da ida da Comissão ao local, o II Encontro dos Torturados e Torturadas da Guerrilha do Araguaia, com o apoio da Secretaria Estadual de Direitos Humanos. O sítio transmitia uma calma

da Presidência da República, a Comissão Especial de Mortos e Desaparecidos Políticos e a Comissão de Anistia, além de algumas importantes publicações. As informações até agora obtidas sobre a Guerrilha do Araguaia são fruto de pesquisas desenvolvidas com base em documentos não oficiais (até hoje não admitidos pelas Forças Armadas) e no Relatório Arroyo (relato de Ângelo Arroyo, um dos pouquíssimos sobreviventes do grupo guerrilheiro). Há os livros de Hugo Studart, A lei da selva, e o de Taís Morais e Eumano Silva, Operação Araguaia. A primeira grande publicação oficial do Estado que admite a ocorrência da Guerrilha e traz informações sobre o episódio é o livro Direito à Memória e à Verdade, que traz o resultado dos trabalhos da Comissão Especial sobre Mortos e Desaparecidos Políticos, vinculada à Secretaria Especial dos Direitos Humanos da Presidência da República. Há, por fim, os depoimentos que foram recentemente colhidos pela Comissão de Anistia que se deslocou diretamente para a região com alguns dos seus membros. 
bucólica. Aqui e acolá passavam cachorros e galinhas com seus filhotes, projetavam-se sombras de árvores frondosas alternadas entre o barro e a grama, cantavam os passarinhos e viam-se pequenas flores. O plácido cenário contrastava com o grande número de pessoas que se aglomeravam no local. Nos homens e mulheres ali presentes eram visíveis os sinais de toda uma vida no campo: faces sulcadas como a própria terra que diuturnamente cultivavam; mãos pesadas e calejadas de revolver o chão; pele morena, curtida e enrugada de quem não tem intermediários entre o sol e a terra; olhar longínquo como quem se habituou a mirar o horizonte a cada dia iniciado na lavoura; o recato próprio de quem não pôde deixar de trabalhar para chorar as suas perdas; os gestos bruscos de quem depende diretamente da força das suas mãos e do suor do seu rosto.

Após a abertura do Encontro e da fala das autoridades presentes, os membros da Comissão se dividiram em três turmas para ouvirem, cada qual, o seu grupo de requerentes. As salas em que cada turma ficou assemelhavam-se a uma sala de aula, com cadeiras, mesas e uma lousa. Curioso era que as janelas, localizadas no alto das paredes das salas, eram todas preenchidas com grades, como se as salas fossem uma cela ou um claustro.

Passou-se então a ouvir aquelas pessoas. Falavam daquele período como a época em que a "guerra" aconteceu na região; referiam-se aos guerrilheiros ora como "povo da mata", ora como "os paulistas", ora como "os terroristas"; em quase todos os relatos as impressões dos camponeses sobre aqueles forasteiros eram nitidamente de simpatia e agradecimento por certos favores feitos. Uma senhora que naquele mesmo dia havia empunhado a enxada em sua roça, disse que lembrava da guerrilheira Cristina com carinho, visto que ela havia salvado a vida de uma irmã sua ao fazer o difícil parto de seu sobrinho.

Tal afeição era compartilhada também por quem "trabalhou" de guia para as tropas do exército. O verbo trabalhar aqui é só um eufemismo, pois se tratava de verdadeira servidão. Um senhor de avançada idade, cabelos brancos, tez morena, chapéu coco vestido, ia, com sua fala mansa, revelando aos poucos como foi obrigado a ser guia do exército. As tropas caminhavam pela sua roça à vontade, adentravam a casa que dividia com sua mulher $\mathrm{e}$ filhos, comiam a sua comida, perguntavam pelos "terroristas". Depois o levaram junto para as bases militares construídas na região, como a de Xambioá, mantendo-o preso e à disposição das tropas. Enquanto esperava pelas incursões na mata, tinha de fazer inúmeros serviços, como realizar a limpeza das instalações militares, por exemplo. Uma vez na mata, as instruções eram para, quando avistasse os guerrilheiros, levantar o braço e jogar-se deitado no chão, pois aí começariam os tiros. Este senhor ficou longe de sua casa e dos seus durante cerca de três meses. Nesse meio tempo, sua família esteve à mercê dos soldados. O senhor arrematou o seu depoimento dizendo que, "por derradeiro", sua roça e sua casa foram queimadas e ele aconselhado a sair daquela região limítrofe da mata fechada junto com sua mulher e filhos. 
Ao longo de todos os depoimentos, pôde-se perceber que aquele pessoal não possuía, nem na época da guerrilha, nem agora, muita idéia sobre o que estava acontecendo e o porquê. Os próprios requerimentos foram feitos pela iniciativa de alguns poucos advogados que convenceram aqueles homens e mulheres a pedirem suas indenizações e, é claro, a reservarem uma porcentagem desse valor, caso deferido, aos serviços advocatícios prestados.

A realidade mais palpável é a do medo, do receio, e a memória da violência, uma memória feita de silêncios e de olhares fixos. A presença da brutalidade sofrida ainda permanece na impunidade e poderio de quem outrora não mediu esforços ou escrúpulos para encontrar os guerrilheiros. $O$ major Curió e os seus empregados, à época da ida da Comissão de Anistia para lá, rondavam continuamente a região e ali continuavam a exercer sua influência. Enquanto os membros da Comissão digitavam os termos de depoimento, percebiam ironicamente que a linguagem que agora se viam utilizando era a mesma dos Inquéritos Policiais Militares que liam semanalmente nos autos dos demais requerimentos de anistia. A mesma estrutura, a mesma divisão de frases (que fulano tinha tal ocupação; que havia conhecido três guerrilheiros, etc.). Mais do que isso, percebiam que agora aquelas pessoas eram interrogadas, ao longo do seu depoimento, com o intuito de se tentar saber se elas "colaboraram" com os militares ou se ganharam lotes de terra do Incra. Nos interrogatórios militares dos anos 70, ser amigo do "povo da mata" era a acusação, agora a acusação era ter "colaborado" com os militares. É difícil saber até que ponto houve uma colaboração ou um desespero de quem não tinha opções. É o mesmo que tentar saber quem delatou companheiros de militância política porque não agüentou as torturas ou quem o fez para obter vantagens pessoais. A análise tem de ser feita caso a caso.

De todo modo, apesar desses ecos de inquérito, contra o qual se deve sempre estar alerta, a tônica dos depoimentos foi a do testemunho, do paradoxo da necessidade de contar o inenarrável. Não se trata de reproduzir o fato com documentos, mas sim de fazer justiça escutando quem fala do seu sofrimento. O curioso, porém, é que o essencial do sofrimento não pode ser falado, pois é feito de silêncios. O mesmo silêncio que podia ser visto nos olhos amargurados de duas filhas que lembravam as torturas, as humilhações e as prisões sofridas pelo seu pai, amigo dos jovens guerrilheiros que foram chacinados na floresta. Há verdades que só podem ser captadas vivendo, experimentando, especialmente as do oceano de palavras mudas que são as dores, as derrotas, os fracassos, e que não fazem distinção social, atingindo a qualquer um.

Recuperar a memória significa trazer ao presente o passado, aquele que ficou ausente. É no cultivo e no resgate dessa e de todas as histórias negadas pelo avanço impiedoso da civilização que se poderá ser capaz de se tornar mais humano, de voltar a se indignar com as injustiças e de não esquecer a barbárie que se esconde por trás de cada cena da vida cotidiana.

Curiosamente, nos dias presentes, uma das grandes chances que o Brasil tem de fortalecer e preservar a sua memória política vem junto com uma 
palavra que, em sua raiz grega, significa esquecimento: Anistia. Historicamente, tal palavra tem sido utilizada para o perdão concedido pelo Estado aos que no passado recente realizaram atos considerados criminosos pelo regime então em vigor. Tais "crimes", via de regra, guardam sempre uma conotação política e, logo que "perdoados" são prontamente esquecidos.

A anistia política trazida na Constituição brasileira de 1988 (art. $8^{\circ}$ do ADCT) e regulamentada pela lei 10.559/2002 não pode mais ser encaixada no tradicional sentido da anistia. Aqui fica claro o reconhecimento de que quem cometeu o maior crime não foram os perseguidos políticos, mas sim aqueles que os perseguiam: os agentes estatais. Ao invés de o Estado perdoar ele é quem pede o perdão ${ }^{49}$, ele é que reconhece que errou quando prendeu, torturou e matou aqueles que estavam sob sua tutela, quando, mediante um golpe violento e antidemocrático implodiu a ordem constitucional vigente.

É por meio de atividades institucionais como as da Comissão de Anistia que, no contexto brasileiro, torna-se possível o resgate explícito de um passado negado, negociado e negligenciado. É por meio dessas testemunhas que tornam públicas as suas histórias, relatos e impressões em cada processo julgado e apreciado, que uma história diferente do país está sendo construída. Esses arquivos são infinitamente mais valiosos que aqueles que as Forças Armadas não querem ainda revelar, pois trazem a narração das vítimas, pois incitam a sociedade a se transformar de espectador em ouvinte. E é com tal transformação que se pode produzir um caldo de cultura política que viabilize uma sociedade menos violenta e mais solidária.

\section{Política, responsabilidade e redenção}

Foi dito, no início deste texto, que a política, a partir do século XX, assume a feição de uma política de luto. É possível perceber agora que este luto não significa o imobilismo de uma interminável lamentação do passado ou de um "não virar a página", mas sim a necessidade de que o presente seja transformado pela recuperação do passado, não pela sua repetição. Recuperar o passado é tarefa da memória, de uma memória que se põe à escuta daquilo que foi esquecido, que se dá em meio a uma comunidade de narradores, que vêm e vão para todos os $\operatorname{lado}{ }^{50}$, que não cabem nos encaixes calculados da história linear e de um tempo vazio.

49 Sempre que o perseguido ou perseguida política, ou então algum familiar ou representante, está presente na sessão de julgamento do seu requerimento de anistia junto à Comissão de Anistia, o Conselheiro ou Conselheira que preside a sessão, ao final do julgamento que deferiu o reconhecimento da condição de anistiada ou anistiado político, em tom solene pede desculpas em nome do Estado brasileiro por toda a perseguição, prejuízo e sofrimento que lhe foi causado.

50 Tal aspecto é destacado por Benjamin quando diz que : "Comum a todos os grandes narradores é a facilidade com que se movem para cima e para baixo nos degraus de sua experiência, como numa escada. Uma escada que chega até o centro da terra e que se perde nas nuvens - é a imagem de uma experiência coletiva, para a qual mesmo o mais profundo choque da experiência individual, a morte, não representa nem um escândalo nem um impedimento" (BENJAMIN, 0 narrador, p. 215). 
Trata-se, portanto, da necessidade de uma transformação de espectadores para testemunhas, o que pode ser feito quando se é ouvinte, quando se recebe a experiência "como um anel", quando se compartilha o inenarrável, quando a memória do involuntário presente na dimensão coletiva das gerações precedentes é escutada. Como assinala Reyes Mate, o papel da memória é modesto. Ela não promete e não garante nenhuma solução que possa resolver aquilo que está pendente, ela apenas recoloca a pergunta e a atualiza, resgatando-a da indiferença ${ }^{51}$. Quem ouve torna-se responsável pela continuidade da narração, passa a fazer parte dela. Diante do sofrimento e da injustiça não ouvir é cometer uma segunda injustiça, é lavar as mãos e não assumir a responsabilidade que as gerações precedentes passaram para a atual, é despejar os pais e avós nos sanatórios e hospitais para mantê-los bem longe da vista, justamente quando iriam transmitir sua experiência, com a altivez de quem está no alto e no limite da sua existência.

Se é verdade que "tudo é campo", a solução está, primeiramente, em se reconhecer isto, encarando o campo de frente. Para que o humano possa se redimir ele tem de se tornar totalmente responsável. É uma responsabilidade absoluta que não pode ser terceirizada para Deus ou qualquer outra divindade. É preciso que os homens e mulheres, que compõem o coletivo social e ocupam os assentos construídos pela cultura, assumam para si a tarefa de fazer justiça às vítimas do passado e de manter inabalável a atenção constante no presente, receptiva à fragilidade e à delicadeza da diferença, da identidade que se afirma outra a cada instante, do compromisso de construir uma sociedade verdadeiramente democrática.

Somente dessa aceitação e dessa responsabilidade assumida é que pode surgir a redenção, a salvação a reconciliação. Por isto Benjamin fala de uma política messiânica, pois ela aponta para uma alteridade fundadora que pode recolher eternamente os esquecimentos do mundo à espera de que sejam recuperados pelo mundano. Benjamin traz aqui, na parte final de suas Teses, toda a influência da mística judaica ${ }^{52}$ para indicar a vinda do Messias:

Certamente, os adivinhos que interrogavam o tempo para saber o que ele ocultava em seu seio não o experimentavam nem como vazio nem como homogêneo. Quem tem em mente esse fato, poderá talvez ter uma idéia de como o tempo passado é vivido na rememoração: nem como vazio, nem como homogêneo. Sabe-se que era proibido aos judeus investigar o futuro. Ao

51 Diz Reyes Mate que a "memória tem essa função vital, que é muito modesta, em qualquer caso, pois, pode atualizar a pergunta sem que esteja em sua mão a resposta. Claro que sem a pergunta tampouco cabe esperar resposta. São dois olhares, pois sobre a mesma história: o do homem moderno que endossa o sofrimento humano, custo do progresso, ao capítulo da fatalidade natural e a do anjo da história ou do alegorista que vê nele uma responsabilidade do homem" (MATE, op. cit., p. 236).

52 Importa observar aqui que os conceitos e categorias teológicas, como redenção e messiânico, que assomam nos textos de Benjamin ali estão para demarcar uma ação radicalmente mundana. 
contrário, a Tora e a prece se ensinam na rememoração. Para os discípulos, a rememoração desencantava o futuro, ao qual sucumbiam os que interrogavam os adivinhos. Mas nem por isso o futuro se converteu para os judeus num tempo homogêneo e vazio. Pois nele cada segundo era a porta estreita pela qual podia penetrar o Messias ${ }^{53}$.

Diante da inumanidade do sofrimento e da barbárie nem toda boa vontade e compreensão humanas podem consolar. O mal radical só pode ser perdoado por algo que seja tão inumano quanto ele: o messiânico ${ }^{54}$. Mas nada garante que tal redenção venha. Resta ao mundano a espera, na mantença daquela atenção constante, do respeitoso silêncio diante das injustiças e das vítimas. Para que exista este respeito, é preciso que os algozes se arrependam dos seus atos, que eles desejem que tais atos nunca tivessem acontecido, tal é o que torna possível a reconciliação ${ }^{55}$. Os algozes aqui não são simplesmente as pessoas que mataram, torturaram, perseguiram, seqüestraram e destroçaram. Trata-se de se reconhecer como parte de uma sociedade que chancela o acionamento da máquina que cria o mal sem responsabilidade, o mal sem rosto, o mal radical. As grandes obras modernas, as vidas cheias de conforto e produtos, as riquezas e fortunas, a manutenção da ordem, do ordinário, da norma, do normal, se erguem sobre "os corpos dos que estão prostrados no chão".

A reconciliação é, assim, uma tarefa sempre em andamento, é o resultado ao qual se pode aspirar por uma renovada política, que aceite o desafio de incluir sem excluir. A dimensão político-jurídica institucional se, por um lado mantém a violência, também é o que permite a inclusão do que está à margem, esquecido ${ }^{56}$.

53 BENJAMIN, Sobre o conceito de história, p. 232.

54 GAGNEBIN, op. cit., p. 112.

50 Neste sentido, a experiência das Comissões de Verdade e Reconciliação que tiveram lugar na África do Sul são emblemáticas. A África do Sul esteve envolvida de 1948 a 1988 em um regime comandado pelo Partido Nacional que se apoiava fortemente na segregação racial e que ficou mundialmente conhecido pelo nome de "apartheid". Sérias violações aos Direitos Humanos foram praticadas. A transição democrática deflagrada ao final desse período optou por formar Comissões de Verdade e Reconciliação, coordenadas pelo Arcebispo Tutu, que eram pautadas pelo princípio da publicização e recuperação do passado para construir um futuro alicerçado no reconhecimento das indignidades sofridas. Trata-se de enfatizar o enfoque positivo da verdade na construção da cidadania e não de esquecer um passado traumático e doloroso. Um dos procedimentos adotados por essas Comissões era o de permitir aos violadores dos Direitos Humanos, sejam eles do governo anterior ou não, também darem, além das vítimas, os seus testemunhos, procurando envolvê-los em uma esfera de reconciliação e admissão do erro, promovendo, inclusive, a reconciliação e o perdão entre alguns que foram violados e os que os violaram.

56 Neste sentido é que, de modo pertinente, argumenta Reyes Mate (op. cit., p. 117-118), delimitando o desafio de uma "universalidade sem exclusões". Insere-se na tradição que busca esse Direito que emancipa, que inclui e que liberta a lapidar formulação de Roberto Lyra Filho de que "o Direito é a legítima organização social da liberdade" (LYRA FILHO, Roberto. O que é direito. 12. ed. São Paulo: Brasiliense, 1991. p. 86). José Geraldo de Sousa Junior, herdeiro da inspiração de Lyra Filho, na defesa de sua tese de doutorado ocorrida no 
É, por fim, somente na busca de uma memória plena que a humanidade poderá se redimir. Nada pode se perder, "somente a humanidade redimida poderá apropriar-se totalmente do seu passado"57. Este momento de um encontro total seria o próprio fim da história, a indicação de um outro tempo, a possibilidade de um alegre esquecimento ${ }^{58}$, da conquista da leveza de um anjo, cuja única preocupação seria cantar em louvor.

\section{Referências}

ADORNO, T. W. Mínima moralia. Tradução de Artur Morão. Lisboa: Edições 70, 2001.

. Dialectica negativa. Tradução de Alfredo Brotons Muñoz. Madrid: Akal, 2005.

AGAMBEN, G. Homo Sacer: o poder soberano e a vida nua I. Belo Horizonte: UFMG, 2004.

ARENDT, H. Origens do totalitarismo - anti-semitismo, imperialismo e totalitarismo. Tradução de Roberto Raposo. São Paulo: Companhia das Letras, 1989.

BENJAMIN, W. Sobre o conceito da história. In: BENJAMIN, Walter. Magia e técnica, arte e política ensaios sobre literatura e história da cultura - Obras escolhidas I. 7.ed. Tradução de Sérgio Paulo Rouanet. São Paulo: Brasiliense, 1994. [Obras Escolhidas; v. 1].

.Experiência e pobreza. In: BENJAMIN, Walter. Magia e técnica, arte e política-ensaios sobre literatura e história da cultura - Obras escolhidas, I. 7. ed. Tradução de Sérgio Paulo Rouanet. São Paulo: Brasiliense, 1994. [Obras escolhidas, v. 1].

. O narrador - considerações sobre a obra de Nikolai Leskov. In: BENJAMIN, Walter. Magia e técnica, arte e política - ensaios sobre literatura e história da cultura - Obras escolhidas I. 7.ed. Tradução de Sérgio Paulo Rouanet . São Paulo: Brasiliense, 1994. [Obras escolhidas, v. 1].

. A obra de arte na era de sua reprodutibilidade técnica. In: BENJAMIN, Walter. Magia e técnica, arte e política - ensaios sobre literatura e história da cultura - Obras escolhidas, I. 7. ed. Tradução de Sérgio Paulo Rouanet. São Paulo: Brasiliense, 1994. [Obras Escolhidas, v. 1].

. Franz Kafka - a propósito do décimo aniversário de sua morte. In: BENJAMIN, Walter. $\overline{M a g i a}$ e técnica, arte e política - ensaios sobre literatura e história da cultura-Obras escolhidas, I. 7. ed. Tradução de Sérgio Paulo Rouanet . São Paulo: Brasiliense, 1994. [Obras escolhidas, v. 1]. BOFF, L. Inquisição: um espírito que continua a existir. Prefácio. In: EYMERICH, Nicolau. Manual dos inquisidores. Comentários de Francisco Peña. Trad. Maria José Lopes da Silva. 2. ed. Rio de Janeiro: Rosa dos Tempos; Brasília: Fundação Universidade de Brasília, 1993.

BRASIL. Secretaria Especial dos Direitos Humanos. Comissão Especial sobre Mortos e Desaparecidos Políticos. Direito à verdade e à memória. Brasília: Secretaria Especial dos Direitos Humanos, 2007.

dia 16 de junho de 2008 na Universidade de Brasília, ao responder a uma de suas argüidoras sobre qual era a "rua" da qual falava o Projeto "Direito Achado na Rua", disse que ela é aquela que leva ao coração dos homens, ou seja, que os torna testemunhas diante da experiência da exclusão e da negação dos direitos mais básicos da pessoa humana (SOUSA JUNIOR, José Geraldo de. Direito como liberdade: o Direito Achado na Rua - experiências populares emancipatórias de criação do direito. 2008. 320 f. [Tese de Doutorado] - Programa de PósGraduação em Direito da Universidade de Brasília. Brasília.

57 BENJAMIN. Sobre o conceito de história, p. 223.

58 Em seu livro, Gagnebin assinala a grande influência da noção nietzscheana de um "alegre esquecimento" na obra de Benjamin, que assinala uma noção positiva do esquecimento, que não confunde a tarefa da memória com a repetição de um ressentimento vingativo ou de qualquer atitude revanchista (GAGNEBIN, op. cit., p. 110). 
DOSTOIÉVSKI, F. O idiota. Tradução de Paulo Bezerra. São Paulo: Editora 34, 2002.

GAGNEBIN, J. M. História e narração em Walter Benjamin. 2. ed. São Paulo: Perspectiva, 2004.

GONZÁLEZ, R. S. Direitos Humanos na América Latina hoje: heranças de transições inconclusas. In: KEIL, I.; VIOLA, S.; ALBUQUERQUE, P. [Orgs.]. Direitos humanos: alternativas de justiça social na América Latina. São Leopoldo: UNISINOS, 2002.

LEVI, P. É isto um homem? Tradução de Luigi Del Re. 2. ed. São Paulo: Rocco, 1997.

LYRA FILHO, R. O que é direito. 12. ed. São Paulo: Brasiliense, 1991.

MATE, R. Memórias de Auschwitz - atualidade e política. Tradução de Antonio Sidekum. São Leopoldo: Nova Harmonia, 2005.

PROUST, M. No caminho de Swann. Tradução de Mário Quintana. 2. ed. Rio de Janeiro: Globo, 1956.

RIBEIRO, D. O povo brasileiro: a formação e o sentido do Brasil. 2. ed. São Paulo: Cia. Das Letras, 1996.

RICOEUR, P. O si-mesmo como um outro. Tradução de Lucy Moreira César. Campinas: Papirus, 1991.

ROSA, J. G. Magma. Rio de Janeiro: Nova Fronteira, 1997.

SILVA FILHO, J. C. M. da. Pessoa humana e boa-fé objetiva nas relações contratuais: a alteridade que emerge da ipseidade. In: SILVA FILHO, José Carlos Moreira da; PEZZELLA, Maria Cristina Cereser (Orgs.). Mitos e rupturas no direito civil contemporâneo. Rio de Janeiro: Lumen Juris, 2008. p. 291-323.

SOUSA JUNIOR, J. G. de. Direito como liberdade: o Direito Achado na Rua - experiências populares emancipatórias de criação do direito. 2008. 320f. [Tese de Doutorado] - Programa de PósGraduação em Direito da Universidade de Brasília. Brasília.

TÓLSTOI, L. A morte de Ivan Ilitch. Tradução de Vera Karam. Porto Alegre: L\&PM, 2002. 